\begin{tabular}{|c|c|c|}
\hline$\varepsilon^{R^{2}}$ & $\begin{array}{c}\text { ABDIMAS: Jurnal Pengabdian Masyarakat Universitas Merdeka Malang } \\
\text { Vol.6(4) November 2021, 600-612 } \\
\text { p-ISSN: 2721-138X e-ISSN: 2548-7159 } \\
\text { http://jurnal.unmer.ac.id/index.php/jpkm }\end{array}$ & $\begin{array}{l}\text { LPPM } \\
\text { UNMER } \\
\text { MALANG }\end{array}$ \\
\hline
\end{tabular}

\title{
Alternative Empowerment Program in narcotics-prone areas and implications for family resilience
}

\section{Program Pemberdayaan Alternatif di kawasan rawan narkotika dan implikasinya terhadap ketahanan keluarga}

\author{
Fika Dewi Rahmawati, Adis Imam Munandar, Palupi Lindiasari Samputra \\ Sekolah Kajian Stratejik dan Global, Universitas Indonesia \\ Jl. Salemba Raya No. 4, Jakarta Pusat, DKI Jakarta, 10430, Indonesia
}

\begin{abstract}
ARTICLE INFO
Received: 2021-02-18

Revised: 2021-03-15

Accepted: 2021-05-05

Keywords:

Alternative empowerment, Family resilience, Narcotics

prone areas,

the Indonesian National

Narcotics Agency

\section{ABSTRACT}

Community empowerment through alternative activities in narcotic-prone areas is needed to minimize narcotics circulation. This activity aims to analyze the effectiveness of the Alternative Empowerment Program that has been carried out by the Indonesian National Narcotics Agency for North Jakarta City. The method used is qualitative with descriptive analysis. The activity was carried out in RW 12, Muara Bahari Village, Tanjung Priok, North Jakarta. Collecting data through observation and interviews with field implementing officers, community leaders, and residents who take part in alternative empowerment programs. Analysis of the effectiveness of the program was carried out after the alternative empowerment activities were carried out for 2 years. The results of the Alternative Empowerment Program are in accordance with the needs and implementation in the field. The program can increase economic independence and welfare but has not been maximized in reducing the number of narcotics crimes, crimes, and professions for people in vulnerable areas. Through the Alternative Empowerment Program, there will be a strengthening of the household economy which can increase family resilience for people in narcotic-prone areas.
\end{abstract}

(C)2021 Published by University of Merdeka Malang. This is an open access article distributed under the CC BY-SA 4.0 license (https://creativecommons.org/licenses/by-sa/4.0/)

How to cite: Rahmawati, F. D., Munandar, A. I., \& Samputra, P. L. (2021). Alternative empowerment programs in narcotics-prone areas and implications for family resilience. Abdimas: Jurnal Pengabdian Masyarakat Universitas Merdeka Malang, 6(4), 600-612. https://doi.org/10.26905/abdimas.v6i4.5497

\section{PENDAHULUAN}

Jakarta sebagai Ibu Kota Negara Indonesia tidak terlepas dari maraknya peredaran narkotika. Menurut data kawasan rawan tahun 2019 (Puslitdatin, 2020), DKI Jakarta menempati urutan pertama dengan memiliki 117 titik kawasan rawan narkotika. Sedangkan dalam pengungkapan kasus narkotika, DKI Jakarta menempati urutan terbesar kedua di Indonesia yaitu dengan 5.885 pengungkapan kasus narkotika (Puslitdatin, 2020). Dari banyaknya kawasan rawan narkotika yang ada di Jakarta, terdapat 32 titik kawasan rawan di wilayah Jakarta Utara yang tersebar di 6 (enam) kecamatan (P2M, 2019). 


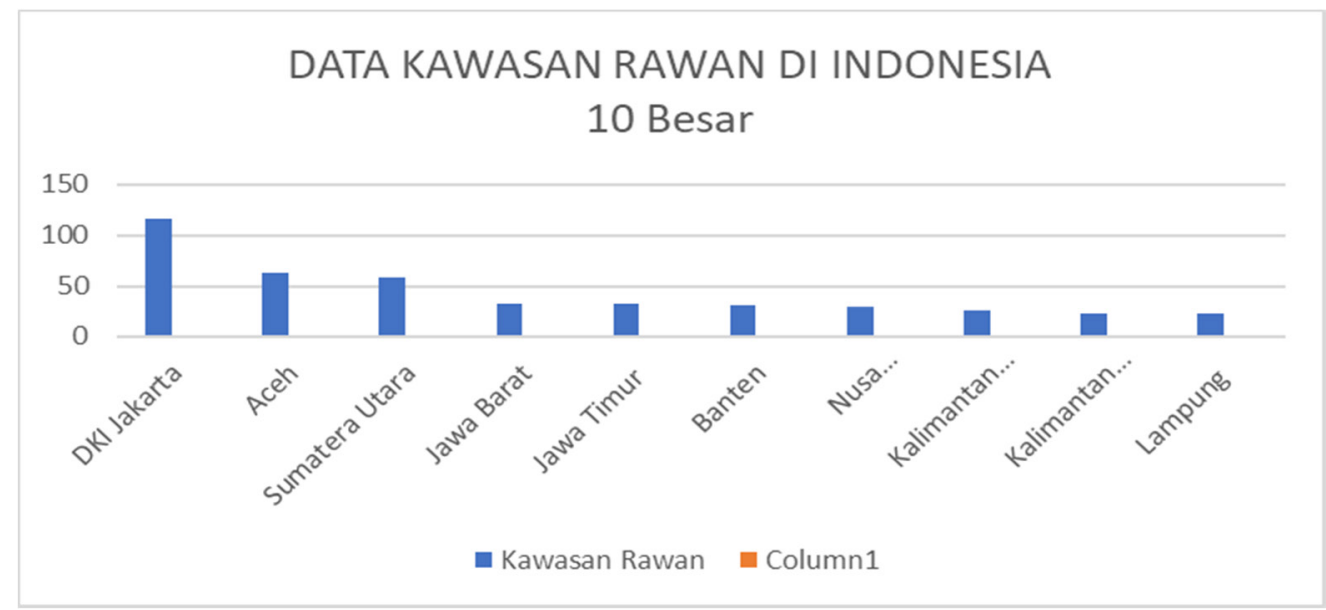

Gambar 1. Data kawasan rawan di Indonesia (10 Besar) Sumber: BNN, 2019

Salah satu kawasan rawan narkotika di Jakarta Utara di antaranya adalah Kampung Muara Bahari, Tanjung Priok, Jakarta Utara. Kawasan tersebut masuk ke dalam kategori kawasan rawan narkotika karena memenuhi karakteristik pokok dan karakteristik pendukung (Dayamas, 2017). Berdasarkan karakteristik yang sudah ditentukan tersebut dilakukan pemetaan oleh BNN Kota Jakarta Utara untuk mengetahui kawasan mana saja yang rawan terhadap kejahatan narkotika. Salah satu kawasan yang rawan yaitu di Kampung Muara Bahari, yang memenuhi tujuh dari delapan kriteria pokok yaitu: (1) Adanya kasus kejahatan narkotika; (2) Kriminalitas dan kekerasan; (3) Keberadaan bandar/pengedar narkotika; (4) Adanya pengguna narkotika; (5) Ditemukannya barang bukti narkotika; (6) Sebagai pintu masuk narkotika; dan (7) Adanya kurir narkotika. Selain itu, terdapat tiga dari lima kriteria pendukung yang terpenuhi yaitu: (1) Banyak lokasi hiburan; (2) Tingginya angka kemiskinan; dan (3) Ketiadaan sarana publik (P2M, 2019).

Tabel 1. Karakteristik kawasan rawan narkotika

\begin{tabular}{ll}
\hline \multicolumn{1}{c}{ Indikator Karakteristik Pokok } & \multicolumn{1}{c}{ Indikator Karakteristik Pendukung } \\
\hline Kasus kejahatan narkotika & Banyak lokasi hiburan \\
Angka kriminalitas/aksi kekerasan & Tempat kost dan hunian dengan privacy tinggi \\
Bandar pengedar narkotika & Tingginya angka kemiskinan \\
Kegiatan produksi narkotika & Ketiadaan sarana publik \\
Angka pengguna narkotika & Rendahnya interaksi sosial masyarakat \\
Barang bukti narkotika & \\
Entry point narkotika & \\
Kurir narkotika & \\
\hline
\end{tabular}

Untuk mengatasi kerawanan narkotika di kawasan tersebut, maka BNN Kota Jakarta Utara menyelenggarakan program Pemberdayaan Alternatif, sebagai bentuk dari pemberdayaan masyarakat. 
ABDIMAS: Jurnal Pengabdian Masyarakat Universitas Merdeka Malang Volume 6, No. 4, November 2021: 600-612

Pemberdayaan masyarakat sendiri diartikan sebagai sebuah pendekatan atau strategi dimana masyarakat diberi kekuasaan dan kekuatan (community empowering) dengan cara memberikan peningkatan pengetahuan dan keterampilan agar mampu mengidentifikasi dan membuat prioritas kebutuhan mereka dan mencari sumber daya untuk mengatasi masalah dan mengambil aksi secara bersama-sama (Dayatif, 2017). Sedangkan pemberdayaan masyarakat sendiri dapat dilihat dari tiga aspek (Noor, 2011), yaitu sebagai upaya pengembangan (enabling), memperkuat potensi (empowering), dan melindungi (protecting), dimana hal ini dilakukan untuk memampukan dan memandirikan masyarakat. Berdasarkan definisi tersebut dapat dikatakan bahwa pemberdayaan masyarakat pada akhirnya memiliki tujuan untuk membentuk masyarakat yang berdaya guna dan mandiri. Hal ini dilakukan misalnya dengan memberikan berbagai intervensi berupa stimulus dimasyarakat sehingga mereka dapat membangun potensinya untuk kesejahteraan diri dan lingkungannya. Sementara itu program Pemberdayaan Alternatif yang dilakukan di kawasan rawan narkotika ini bertujuan untuk meningkatkan peran dan kemandirian masyarakat di kawasan rawan narkotika guna menciptakan lingkungan yang bebas dan bersih dari penyalahgunaan dan peredaran gelap narkotika.

Program Pemberdayaan Alternatif dilakukan dengan memberikan pelatihan kepada warga sebagai upaya pengembangan diri dan peningkatan keterampilan. Pemberian pelatihan di suatu wilayah terbukti dapat meningkatkan perekonomian dan juga kewirausahaan pada masyarakat yang diberikan pelatihan (Duwi et al., 2019). Melalui program Pemberdayaan Alternatif diharapkan dapat merubah mindset para pelaku kejahatan narkotika dari pekerjaan yang illegal kepada pekerjaan yang legal dan mampu hidup mandiri tanpa bersentuhan dengan narkotika (Dayatif, 2017). Melalui pelatihan yang diberikan diharapkan ke depannya mereka dapat memiliki keahlian dan keterampilan yang dapat digunakan untuk berwirausaha. Kewirausahaan sosial ini memiliki konsep sebagai sebuah solusi dalam menyelesaikan permasalahan sosial karena dapat meningkatkan kesejahteraan masyarakat (Saragih, 2017).

Dalam pelaksanaannya program Pemberdayaan Alternatif di RW.12 Kampung Muara Bahari hanya berlangsung selama dua tahun (2019-2020) dan di tahun berikutnya akan dilakukan di lokasi yang berbeda sesuai dengan Surat Edaran: SE/4/KA/PM.01/2020/BNN. Sedangkan pelaksanaan program Pemberdayaan Alternatif perlu memperhatikan terkait keberlanjutan dari program pemberdayaan yang dilakukan (Fanaqi et al., 2019). Keberlanjutan program merupakan tahap yang harus diperhatikan dalam pemberian pelatihan untuk memastikan program dapat terus berlanjut (Azizah, 2019). Oleh karena itu, perlu kiranya dilakukan analisis terkait pelaksanaan program Pemberdayaan Alternatif di RW.12 KP. Muara Bahari Tanjung Priok untuk melihat efektivitas dari pelaksanaan program yang selama ini sudah dilakukan dan apa saja yang masih perlu diperbaiki.

Berdasarkan penelitian sebelumnya terkait program Pemberdayaan Alternatif yang dilakukan di beberapa wilayah rawan narkotika terdapat beberapa hasil yang berbeda. Dalam penelitian yang dilakukan di kawasan rawan narkotika di Komplek Permata, Jakarta Barat didapati hasil bahwa program telah berjalan sesuai dengan konsep pemberdayaan masyarakat (Yulinda \& Permata, 2013). Sedangkan dalam penelitian yang dilakukan di kawasan rawan narkotika di Kampung Pertanian Jakarta Timur didapatkan hasil bahwa dari aspek ketepatan proses dinilai sudah cukup baik sedangkan dalam dari aspek ketepatan kebijakan ternyata belum dapat dikatakan tepat (Nopitasari et al., 2017). Sementara itu, 
penelitian yang dilakukan di kawasan rawan narkotika di RW.14 Kampung Muara Bahari mengatakan bahwa "Rumah Kreatif dan Inovasi" dinilai membawa banyak perubahan pada masyarakat serta dapat membangun hubungan (silahturahmi) antar warga (Yunia \& Pinariya, 2019). Dari ketiga penelitian tersebut pelaksanaan program Pemberdayaan Alternatif dinilai menggunakan cara yang berbeda-beda, tergantung dari aspek mana peneliti melakukan penilaian. Dalam analisis ini akan dilihat bagaimana efektivitas program Pemberdayaan Alternatif yang telah dilakukan oleh BNN Kota Jakarta Utara dalam dua tahun terakhir (2019-2020).

Permasalahan yang ingin diangkat adalah sejauh mana efektivitas program Pemberdayaan Alternatif yang selama dua tahun terakhir (periode 2019-2020) dijalankan oleh BNN Kota Jakarta Utara di wilayah RW.12 Kampung Muara Bahari, dan bagaimana program Pemberdayaan Alternatif berdampak pada ketahanan keluarga. Ketahanan keluarga secara definisi dapat diartikan sebagai sebuah proses dan hasil yang terkait dengan menolak, mengelola atau mengembalikan keseimbangan sistem keluarga dalam menghadapi resiko yang signifikan (Hanita, 2020). Berbagai ancaman terkait kejahatan narkotika itu lah yang dapat menjadi resiko dan ancaman bagi keluarga dan masyarakat di wilayah tersebut. Berbeda dengan penelitian sebelumnya, analisis Program Pemberdayaan Alternatif dilakukan dengan menganalisa indikator input/proses, indikator output dan indikator efek/dampak. Selain itu, sebagai kebaruan akan dianalisis terkait implikasi program Pemberdayaan Alternatif bagi ketahanan keluarga.

\section{METODE}

Program Pemberdayaan Alternatif dilakukan dengan memberikan pelatihan berupa peningkatan keterampilan/skill kepada warga di kawasan rawan narkotika agar dapat menumbuhkan kemandirian dan meningkatkan penghasilan warga sehingga dapat terhindar dari bisnis narkotika yang marak di wilayah tersebut. Pelatihan keterampilan yang dipilih berfokus pada usaha yang bermodal kecil dan mudah untuk dijual. Untuk melihat sejauh mana proses, output dan dampak dari program Pemberdayaan Alternatif maka digunakan metode kualitatif dengan analisis deskriptif, dimana dilakukan analisis yang mendalam tentang program Pemberdayaan Alternatif di kawasan rawan narkotika, yang terletak di RW.12 Kampung Muara Bahari, Jakarta Utara. Data diperoleh melalui observasi, wawancara, dan data sekunder, yang dilakukan setelah kegiatan Pemberdayaan Alternatif ini dilaksanakan selama 2 tahun. Sementara itu, informan dipilih dengan teknik purposive sampling, yaitu pemilihan informan yang dilakukan dengan sengaja sesuai dengan kriteria yang dibutuhkan. Adapun informan yang akan diwawancara adalah petugas pelaksana Program Pemberdayaan Alternatif di RW.12 Kampung Muara Bahari, yaitu petugas BNN Kota Jakarta Utara, tokoh masyarakat di wilayah RW.12, dan warga penerima pelatihan di RW.12. Adapun analisis terhadap program Pemberdayaan Alternatif meliputi indikator input/proses, output, dan juga efek/dampak. Gambar 2 adalah tahapan pelaksanaan program Pemberdayaan Alternatif yang dilakukan di BNN Kota Jakarta Utara, mulai dari input/proses pelaksanaan program, output yang dituju, dan juga efek/dampak yang diharapkan. 
ABDIMAS: Jurnal Pengabdian Masyarakat Universitas Merdeka Malang Volume 6, No. 4, November 2021: 600-612

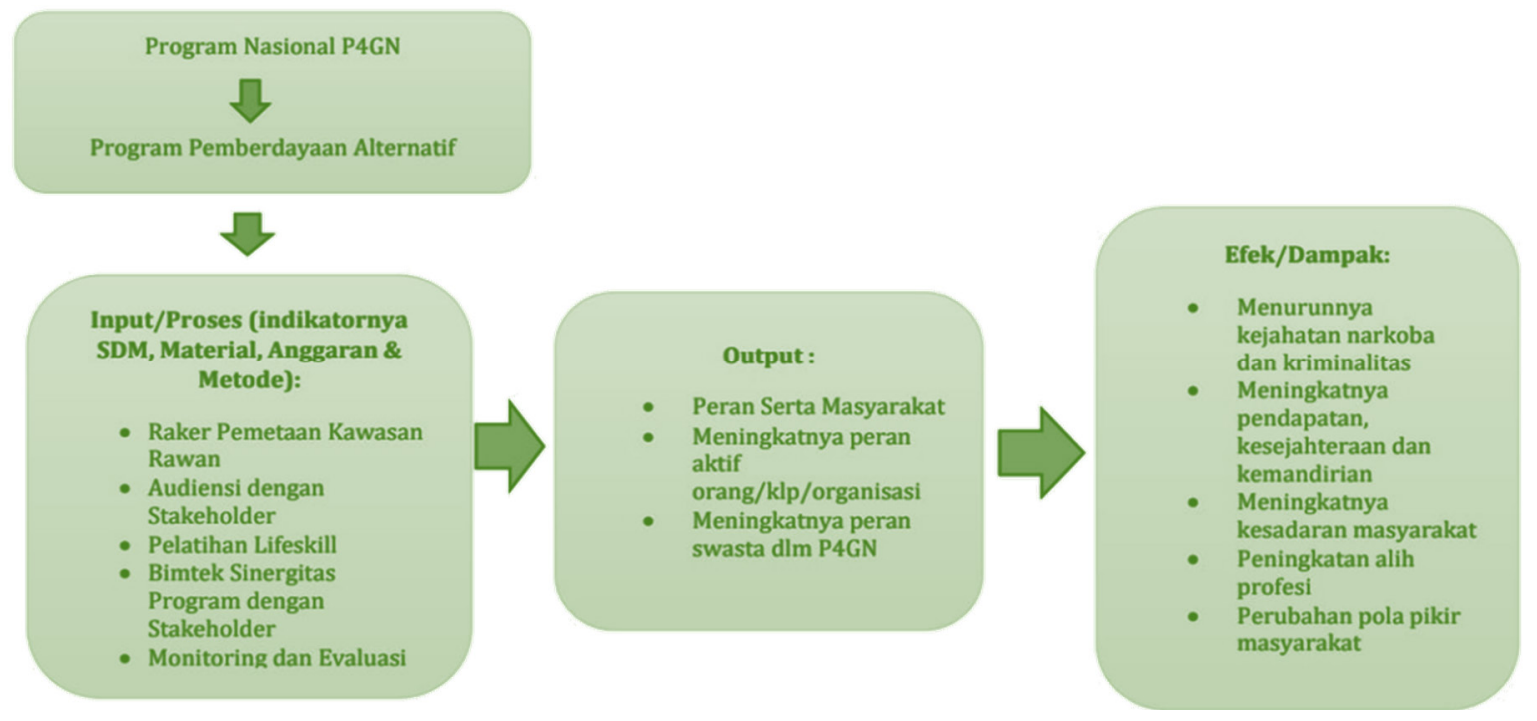

Gambar 2. Tahapan program pemberdayaan alternatif

\section{HASIL DAN PEMBAHASAN}

Program pelatihan yang diberikan BNN Kota Jakarta Utara sudah diberikan dua kali pada tahun 2019 dan 2020. Pelatihan pertama di RW.12 dilaksanakan pada tahun 2019 berupa pelatihan pembuatan cheese stick, pembuatan minuman kopi, dan pembuatan boneka flannel. Sedangkan pelatihan kedua diadakan tahun 2020 berupa pelatihan pembuatan roti manis, pembuatan masker dan tote bag, dan juga pelatihan pemasaran bagi peserta, dimana pelatihan total diikuti oleh 30 orang peserta yang merupakan masyarakat di wilayah RW.012 Kampung Muara Bahari yang rawan peredaran gelap narkotika.
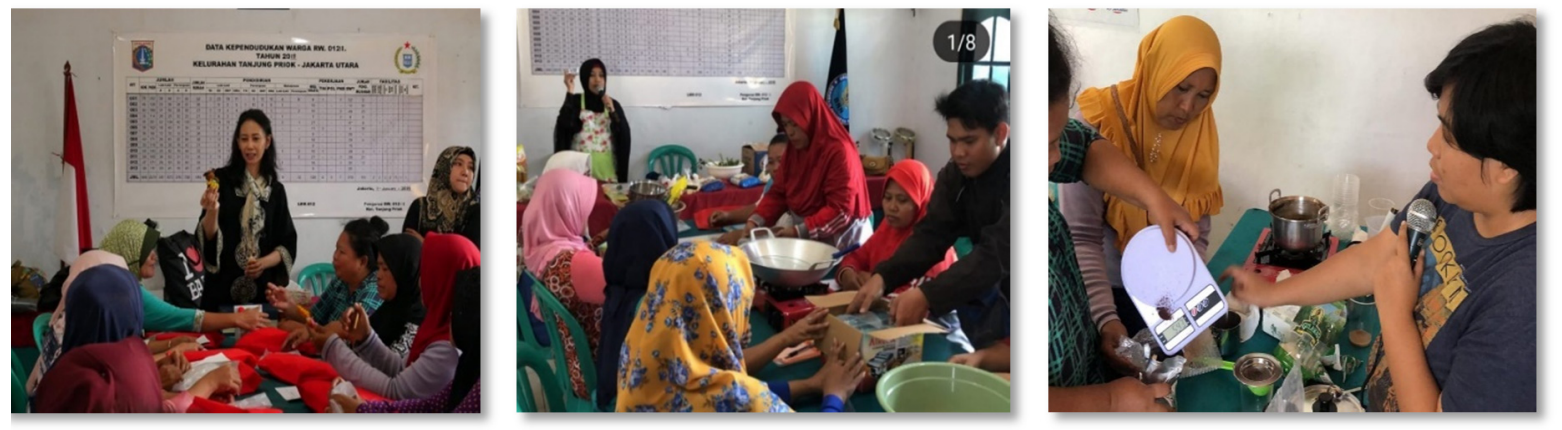

Gambar 3. Program Pemberdayaan Alternatif tahun 2019

Pelatihan Pemberdayaan Alternatif pada tahun 2019 (Gambar 3) diikuti oleh 15 orang peserta dari warga RW.012 KP. Muara Bahari Jakarta Utara. Pelatihan diikuti oleh ibu-ibu dan berlangsung di kantor RW, selama tiga hari. Jalannya kegiatan mulai dari hari pertama sampai ketiga berurutan pada gambar (kiri ke kanan) yaitu hari pertama berisi pelatihan pembuatan boneka flannel, hari kedua pelatihan 
pembuatan cheese stick, dan hari ketiga pelatihan pembuatan kopi. Peserta pelatihan juga diberikan modal berupa peralatan dan bahan agar mereka dapat langsung berjualan.
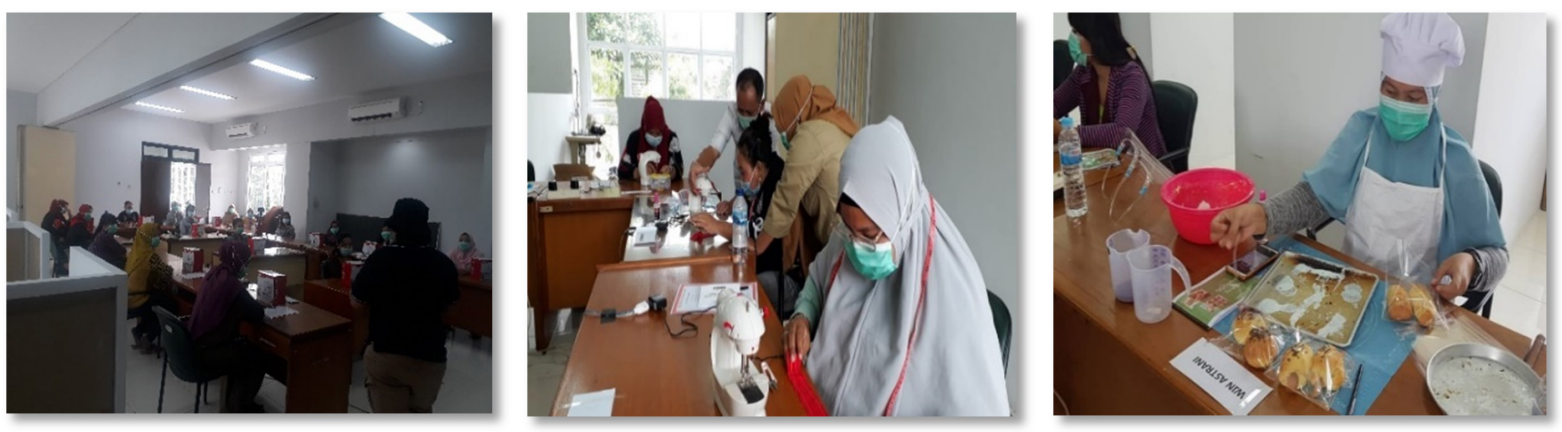

Gambar 4. Program Pemberdayaan Alternatif tahun 2020

Sementara pada Gambar 4 memperlihatkan pelatihan Pemberdayaan Alternatif yang dilakukan tahun 2020. Dimana pelatihan ini diikuti oleh warga RW.012 KP. Muara Bahari Jakarta Utara, yang berjumlah 15 orang dan terdiri dari remaja dan ibu-ibu. Pelatihan berlangsung selama tiga hari di kantor BNN Kota Jakarta Utara. Berurutan pada gambar (kiri ke kanan), pada hari pertama diberikan pelatihan pembuatan roti manis, hari kedua diberikan pelatihan pembuatan tote bag dan masker kain, dan hari ketiga diberikan pembekalan pemasaran. Selanjutnya peserta dibekali dengan modal berupa peralatan dan bahan agar dapat langsung memulai usaha.
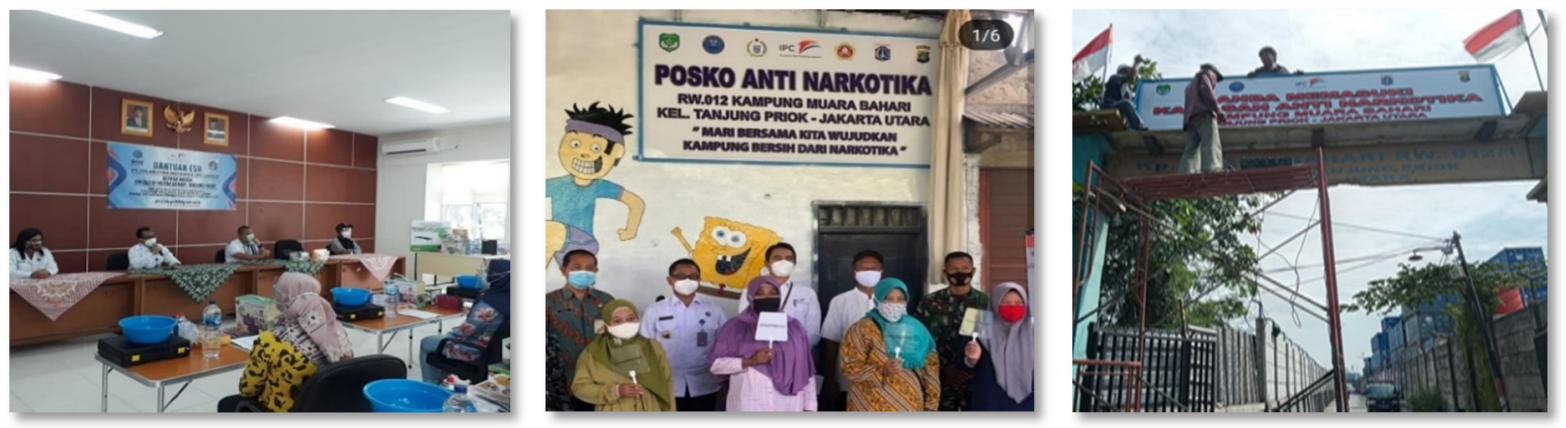

Gambar 5. Peresmian pembangunan posko dan gapura oleh pihak swasta

Sedangkan pada Gambar 5 terlihat bentuk kerja sama antara pihak swasta dan BNN Kota Jakarta Utara. Berurutan pada gambar (kiri ke kanan) yaitu yang pertama pembangunan Posko Anti Narkotika, pembangunan gapura di pintu masuk, dan pemberian pelatihan bagi warga oleh pihak swasta. Pelatihan dari pihak swasta diberikan kepada warga yang belum pernah mendapatkan pelatihan sebelumnya karena banyak warga yang berminat mengikuti pelatihan. Sedangkan pembangunan posko dan gapura sebagai bentuk semangat perlawanan terhadap kejahatan narkotika di sana. 
ABDIMAS: Jurnal Pengabdian Masyarakat Universitas Merdeka Malang

Volume 6, No. 4, November 2021: 600-612

Analisis dilakukan dari tiga indikator dalam program yaitu, indikator input/proses, indikator output, dan indikator efek/dampak. Dimana pemberdayaan sendiri dapat dilihat dari dua hal yaitu sebagai sebuah proses dan juga sebagai tujuan (Fitriani et al., 2011). Apabila dilihat sebagai proses, pemberdayaan dapat diartikan sebagai rangkaian kegiatan untuk memperkuat kekuasaan atau keberdayaan kelompok masyarakat yang lemah. Sementara itu, apabila pemberdayaan dilihat sebagai tujuan maka pemberdayaan dapat dimaknai sebagai keadaan atau hasil yang ingin dicapai dalam perubahan sosial di masyarakat agar menjadi berdaya dan memiliki kekuatan dan kemampuan untuk memenuhi kebutuhan hidupnya baik yang bersifat fisik, ekonomi ataupun sosial.

\section{Analisis input/proses program Pemberdayaan Alternatif}

Input/proses merupakan aspek awal dari pelaksanaan suatu program, ada beberapa aspek yang dilihat yaitu sumber daya manusia (SDM), material, anggaran, dan metode. SDM terkait dengan kebutuhan sumber daya manusia yang memiliki kemampuan dan keterampilan yang sesuai dalam jalannya program Pemberdayaan Alternatif. Sedangkan anggaran berkaitan dengan kecukupan/ kesesuaian antara anggaran dengan kebutuhan di lapangan. Sedangkan material berkaitan dengan kebutuhan bahan dan alat selama program berlangsung, dan metode berkaitan dengan teknik/cara yang dilakukan dalam program Pemberdayaan Alternatif yaitu dengan memberikan pelatihan keterampilan wirausaha. Dalam analisis ini data diambil dengan melakukan observasi dan wawancara terhadap petugas pelaksana di lapangan. Hal ini dilakukan karena mereka sebagai pelaksana dilapangan merupakan pihak yang mengetahui dan menangani kebutuhan terkait SDM, material, anggaran, dan metode apa yang digunakan dalam pelaksanaan program Pemberdayaan Alternatif.

Dari hasil observasi dan wawancara diketahui bahwa ketersediaan SDM, material (bahan dan informasi), dan anggaran telah dipenuhi oleh instansi, dalam hal ini oleh BNN Kota Jakarta Utara. Secara jumlah, ketiga unsur baik SDM, material, dan anggaran dinilai sudah cukup untuk menjalankan program Pemberdayaan Alternatif yang sudah direncanakan sebelumnya. Hasil wawancara dengan salah satu petugas pelaksana Program Pemberdayaan Alternatif, yaitu Ibu R mengungkapkan bahwa:

"...Cukup karena kita kan sudah tau tugas masing-masing jadi sudah ada pembagian tugas-tugas yang harus ditingkatkan pendekatan dengan stakeholder lebih intens... Soft skill cukup masih bisa dilaksanakan dengan baik tidak ada kendala yang besar ... So far, tidak ada kendala, ketersediaan bahannya cukup kebetulan dianggaran cukup besar untuk alat dan bahan jadi sudah cukup ... Cukup sih mba, alat dan bahan sudah sangat cukup untuk mereka menjalankan usaha."

Sedangkan dalam hal metode, program Pemberdayaan Alternatif merupakan metode pemberdayaan untuk masyarakat dengan cara memberikan sejumlah pelatihan untuk meningkatkan skill masyarakat di kawasan rawan narkotika. Adapun tujuan dari peningkatan skill tersebut adalah untuk meningkatkan kemandirian dan penghasilan masyarakat di kawasan rawan narkotika sehingga mereka dapat menghidupi keluarganya secara mandiri dan tidak terbawa/terpengaruh dalam bisnis narkotika yang banyak terjadi di kawasan rawan. Hasil wawancara dengan salah satu Petugas Pelaksana Program Pemberdayaan Alternatif, yaitu Ibu R mengungkapkan bahwa: 
"...Metodenya kita kasih pelatihan ke warga supaya mereka bisa jualan kan kita kasih bantuan alat dan bahan juga... Tujuan programnya untuk menciptakan lingkungan Kampung Muara Bahari bebas dari penyalahgunaan narkoba, setelah dikasih pelatihan kan mereka bisa buka usaha... Jadi bisa ada penghasilan, bisa mandiri lah... Jadi gak kepengaruh jualan narkoba."

Sehingga dengan demikian program pemberdayaan alternatif apabila dilihat dari aspek input/ proses nya baik segi SDM, material, anggaran maupun metode telah sesuai secara kuantitas dan kualitas dengan tujuan/sasaran pelaksanaan program Pemberdayaan Alternatif. Dalam pelaksanaan program, indikator input/proses berupa SDM dan anggaran sangatlah penting karena SDM dan anggaran dapat menjadi faktor penghambat apabila tidak terpenuhi (Motif et al., 2016).

\section{Analisis output program Pemberdayaan Alternatif}

Sedangkan dalam aspek output terdapat beberapa indikator seperti peran serta masyarakat, meningkatnya peran aktif dari orang/kelompok/organisasi disana, dan meningkatnya peran swasta dalam Pencegahan dan Pemberantasan Penyalahgunaan dan Peredaran Gelap Narkotika (P4GN). Untuk mengetahui output dari program telah dilakukan observasi dan wawancara terhadap pelaksana program, stakeholder yang ada di masyarakat, dan juga kepada warga yang mendapatkan pelatihan.

Dari hasil observasi dan wawancara dapat diketahui bahwa kesadaran masyarakat terhadap bahaya narkotika dan ancaman kejahatan narkotika di wilayahnya telah meningkat. Mereka menyadari bahwa narkotika merupakan zat yang berbahaya. Selain itu, mereka juga mengetahui bahwa lingkungan tempat tinggal mereka beresiko tinggi dan rawan terhadap kejahatan narkotika dan kriminalitas lainnya. Meskipun kesadaran masyarakat sudah mulai tumbuh akan tetapi mereka belum berani mengambil peran secara aktif untuk mencegah kejahatan narkotika di wilayah tempat tinggalnya. Hal ini dikarenakan adanya perasaan takut dan khawatir apabila terlalu vokal dan aktif melakukan upaya P4GN di lingkungannya akan dapat membahayakan keselamatan diri dan keluarganya. Mereka hanya berani melindungi keluarga masing-masing dan aktif melakukan kegiatan-kegiatan positif lainnya di masyarakat seperti kegiatan PKK, Jumantik, Dasawisma, mengikuti pelatihan di kelurahan dan lain-lain. Hal positif lain yang dirasakan adalah meningkatnya keaktifan dari pemuda (Karang Taruna) dalam melakukan kegiatan yang positif di masyarakat seperti kegiatan olahraga, mengikuti pelatihan, menjadi panitia kegiatan dalam perayaan hari besar seperti Hari Kemerdekaan atau Maulid Nabi. Para pemuda Karang Taruna juga sudah mau terlibat dalam kegiatan pelatihan yang dilakukan oleh BNN Kota Jakarta Utara dan tidak lagi menjaga jarak. Hasil wawancara dengan salah satu tokoh masyarakat di masyarakat dengan Bapak A mengungkapkan bahwa:

"...Peranan masyarakat di RW.12 cukup aktif, mengajak masyarakat tidak pake narkoba, ibu-ibu PKK-nya aktif selalu mengingatkan, remaja Karang Taruna nya juga aktif ikut pelatihan, minimal di lingkungan terdekat mereka dari keluarga tetangga nanti kan menular tuh ... Kalau kesadaran secara pribadi-pribadi ada, ada perubahan sedikit-sedikit Bu, kalau secara frontal belum bisa, karena kita kan sifatnya pembinaan bukan pemberantasan ... Sekarang sudah agak aman ... Secara umum sikap masyarakat pasif Bu, mereka mengendalikan anak-anaknya sendiri, dibidang usaha ada kemajuan lah sedikit-sedikit ada pesenan ... Gak berani ambil resiko, lebih baik ini sendiri keluarga sendiri dulu, untuk melarang melaporkan gak berani." 
ABDIMAS: Jurnal Pengabdian Masyarakat Universitas Merdeka Malang Volume 6, No. 4, November 2021: 600-612

Hasil wawancara dengan salah satu Petugas Pelaksana Program Pemberdayaan Alternatif, yaitu Ibu R mengungkapkan bahwa:

"...Ada perubahan mba, mereka sudah berani bersikap tegas, menolak, kalau mereka sudah berani menolak kan nanti kampungnya bisa bersih dari narkoba."

Hasil wawancara dengan salah satu warga peserta Program Pemberdayaan Alternatif, yaitu Ibu L mengungkapkan bahwa:

"...Saya sih jujur aja cuek aja masa bodo, lo yang jalanin, lo yang ketangkep, lo yang tanggung resiko

... Intinya takut, takutnya kalau kita ngusik dia nanti kita diapa-apain sama dia."

Sedangkan dalam hal peran swasta di RW.12 telah terjadi kerja sama dengan pihak swasta sebagai dukungan terhadap program P4GN di kawasan rawan narkotika. Program Corporate Social Responsibility (CSR) milik PT. Pelindo II telah memberikan dukungan di wilayah RW.12 dalam satu tahun terakhir. Adapun bentuk dukungan PT. Pelindo II yaitu dengan memberikan program bantuan kegiatan pengembangan diri, berupa pemberian pelatihan dan program belajar kepada masyarakat, agar dapat terus meningkatkan kemandirian dan penghasilan warga di kawasan tersebut. Hasil lainnya adalah hasil kerja sama dengan Sudin Koperasi UMKM dan erdagangan Kota di Jakarta Utara dengan mendaftarkan para peserta pelatihan sehingga memiliki izin usaha sendiri. Hasil wawancara dengan salah satu Petugas Pelaksana Program Pemberdayaan Alternatif, yaitu Ibu R mengungkapkan bahwa:

"...Warga ada... Awalnya posko itu udah dibuat oleh warga tapi karena keterabatasan akhirnya dibuatlah itu bersama BNN dan Pelindo ... Dari Pelindo rencananya ada pelatihan sama kemarin ada kursus gitu untuk anak-anak di Posko ... Sasarannya untuk anak-anak biar ada kegiatan yang positif kalau sore."

Dengan demikian, dalam aspek output program Pemberdayaan Alternatif telah berhasil meningkatkan kesadaran individu terkait bahaya penyalahgunaan narkotika dan ancaman kejahatan narkotika dan kriminal yang mungkin timbul di wilayah mereka. Akan tetapi, kesadaran masih dalam lingkup kecil (rumah tangga), dimana mereka belum berani melakukan/mengambil peran secara aktif dalam melakukan upaya P4GN di wilayahnya. Padahal kurangnya pengetahuan/pemahaman serta partisipasi masyarakat dalam menjalankan program P4GN menjadi faktor penghambat bagi penanggulangan narkotika disuatu wilayah (Motif, 2016). Meskipun begitu masyarakat merasa senang dan berharap program pemberdayaan alternatif dan juga bantuan dari swasta dapat terus berjalan dan membantu wilayah mereka bebas dari kejahatan narkotika dan menjadi lingkungan yang aman dan nyaman.

\section{Analisis efek/dampak dari program Pemberdayaan Alternatif}

Dalam analisis efek/dampak terlihat bahwa program Pemberdayaan Alternatif berhasil memberikan efek/dampak yang positif bagi masyarakat di kawasan rawan narkotika. Adapun indikator dari efek/ dampak adalah menurunnya kejahatan narkotika dan kriminalitas lainnya, meningkatnya pendapatan, kesejahteraan dan kemandirian masyarakat di kawasan rawan narkotika, meningkatnya kesadaran masyarakat di kawasan rawan narkotika, peningkatan alih profesi masyarakat yang awalnya menjual narkotika beralih bekerja di bidang lain, dan terjadi perubahan pola pikir masyarakat di kawasan rawan. Untuk mengetahui efek/dampak dari program Pemberdayaan Alternatif ini dilakukan observasi dan 
wawancara dengan petugas pelaksana program Pemberdayaan Alternatif, stakeholder di masyarakat dan juga kepada warga yang mendapat pelatihan. Dari hasil observasi dan wawancara apabila dilihat dari aspek menurunnya kejahatan dinilai masih belum mencapai hasil yang maksimal. Meskipun pelaku kejahatan narkotika tidak lagi terang-terangan berjualan narkotika dengan bebas akan tetapi kejahatan narkotika seperti jual beli dan pemakaian narkotika illegal diduga masih banyak terjadi. Hal ini dikarenakan masih banyak warga dari luar yang datang bertamu ke wilayah mereka secara sembunyi-sembunyi yang diduga untuk membeli narkotika. Begitu pula dengan kejahatan kriminal lainnya yang masih banyak ditemui di wilayah RW.12 seperti penodongan dan juga tawuran pemuda. Hasil wawancara dengan salah satu tokoh masyarakat dengan Bapak A mengungkapkan bahwa:

"... Volume nya menurun, anak-anak juga banyak yang aktif di karang taruna jadi agak berkurang ... Kalau kriminal ya ada penodongan sama masih rawan tawuran."

Hasil wawancara dengan salah satu warga peserta Program Pemberdayaan Alternatif, yaitu Ibu L mengungkapkan bahwa:

"...Sekarang udah agak mendingan, udah aman ... sepi... sepi... semenjak gak ada kriminal ini gak ada yang jual sabu."

Meskipun efek/dampak program Pemberdayaan Alternatif terhadap kejahatan narkotika dan kriminal lainnya dirasa belum berdampak besar akan tetapi program Pemberdayaan Alternatif berdampak positif bagi peningkatan kemandirian dan penghasilan bagi warga di RW.12 Kampung Muara Bahari. Setelah mengikuti program pelatihan dan mendapat bantuan peralatan dan bahan mereka dapat langsung memulai usaha di lingkungan rumahnya sehingga dapat meningkatkan penghasilan dan kesejahteraan bagi keluarganya. Hasil wawancara dengan salah satu Petugas Pelaksana Program Pemberdayaan Alternatif, yaitu Ibu R mengungkapkan bahwa:

"...Nah ada yg sudah aktif berjualan, ada sekitar 8 orang dari 15 orang yang dikasih pelatihan, lumayan kan mba sudah 50 persen."

Para stakeholder di lingkungan RW.12 danjuga masyarakat mulai sadar akan kondisi lingkungannya dan aktif mengikuti kegiatan positif seperti pelatihan yang dilakukan baik oleh BNN Kota Jakarta Utara, swasta ataupun pemerintah. Hal ini menunjukkan bahwa adanya sikap penerimaan dari para stakeholder dan warga untuk mau terlibat aktif. Sedangkan dalam hal alih profesi belum ditemukan warga yang beralih profesi berhenti menjual narkotika. Hasil wawancara dengan salah satu tokoh masyarakat di masyarakat dengan Bapak A mengungkapkan bahwa:

"...Saya gak tau siapa-siapa yang jualan, cuma katanya aja, tapi setahu saya mereka ada usaha lain, dari awal ada usaha lain."

Hasil wawancara dengan salah satu warga peserta Program Pemberdayaan Alternatif, yaitu Ibu L mengungkapkan bahwa:

"...Gak ada... udah keenakan dapet duit, yang ada jualan lagi, ...banyak kali... kalo lagi gak ada kerjaan... gak papa lah gua jadi kurir aja lah lumayan."

Meskipun tujuan awal program ditujukan bagi para pengedar narkotika agar mau beralih profesi akan tetapi dalam pelaksanaannya, program Pemberdayaan Alternatif masih menargetkan masyarakat 
ABDIMAS: Jurnal Pengabdian Masyarakat Universitas Merdeka Malang

Volume 6, No. 4, November 2021: 600-612

umum yang tinggal di kawasan rawan dengan tujuan agar mereka tidak terpengaruh untuk menjalani bisnis narkotika. Karena di lingkungan masyarakat para bandar narkotika juga mempengaruhi masyarakat umum untuk mengikuti bisnis narkotika dengan dijanjikan keuntungan yang besar. Selain itu, data terkait pengedar narkotika sulit didapatkan karena warga yang melakukan bisnis narkotika dilakukan secara tertutup, terkadang mereka juga memiliki bisnis lain untuk mengelabui masyarakat.

Dengan demikian, efek/dampak dari program Pemberdayaan Alternatif di RW.12 Kampung Muara Bahari Tanjung Priok memberi hasil yang beragam pada setiap indikator. Program Pemberdayaan Alternatif berdampak positif pada kemandirian dan peningkatan penghasilan bagi warga. Akan tetapi, program Pemberdayaan Alternatif belum memberikan dampak yang besar pada alih profesi pelaku bisnis narkotika, penurunan jumlah kejahatan narkotika, dan kriminalitas di kawasan tersebut.

\section{Pengaruh program Pemberdayaan Alternatif terhadap ketahanan keluarga}

Program Pemberdayaan Alternatif merupakan suatu program yang dirancang untuk meningkatkan dan memberdayakan potensi dan kekuatan dimasyarakat agar dapat hidup mandiri dan sejahtera. Pemberdayaan ekonomi merupakan salah satu bentuk ketahanan fisik dalam sumber daya keluarga yang perlu diperkuat sebagai upaya peningkatan ketahanan keluarga dalam mencegah penyalahgunaan narkotika pada remaja (Ikawati, 2016). Hal ini sesuai dengan fungsi keluarga sebagai fungsi ekonomi yang harus menghasilkan sesuatu sebagai unit ekonomi dasar dalam masyarakat (Handayani, 2011). Dalam konteks ketahanan keluarga kita hanya akan melihat pada aspek efek/dampak untuk melihat sejauh mana program Pemberdayaan Alternatif dapat memberi efek/dampak kepada ketahanan keluarga.

Dengan melihat dari hasil program Pemberdayaan Alternatif di kawasan rawan narkotika di RW.12 Kampung Muara Bahari Tanjung Priok, maka didapatkan hasil bahwa program Pemberdayaan Alternatif memberi efek/dampak positif terhadap kemandirian dan peningkatan penghasilan warga disana. Hal ini menunjukkan bahwa terdapat penguatan positif dalam aspek ekonomi. Apabila keluarga secara ekonomi memiliki pendapatan yang kurang maka keluarga tersebut akan rawan dari tawaran untuk memperjualbelikan narkotika (Ikawati, 2016). Kemandirian ekonomi yang dimiliki suatu keluarga akan memperkuat ketahanan keluarga tersebut agar tidak terpengaruh dan terjerumus dalam bisnis narkotika. Oleh karena itu, dikatakan bahwa pendapatan tetap dan memadai merupakan salah satu faktor yang mempengaruhi ketahanan keluarga (Subarkah, 2017). Dengan demikian, program Pemberdayaan Alternatif menjadi salah satu cara yang efektif meningkatkan kemandirian ekonomi yang pada akhirnya dapat meningkatkan ketahanan keluarga dari bahaya narkotika.

\section{SIMPULAN DAN SARAN}

Dari hasil analisis program Pemberdayaan Alternatif kawasan rawan narkotika di RW.12 Kampung Muara Bahari, Tanjung Priok dapat disimpulkan bahwa secara input/proses dari program Pemberdayaan Alternatif sudah sesuai antara apa yang direncanakan dan pelaksanaannya di lapangan, baik dari SDM, material, anggaran, dan juga metode yang dilakukan. Sedangkan apabila dilihat dari output program terlihat dari aspek pemberdayaan dan peran aktif masyarakat dirasa masih kurang, hal ini dikarenakan masyarakat belum berani melakukan upaya Pencegahan dan Pemberantasan Penyalahgunaan dan 
Peredaran Gelap Narkotika (P4GN) secara mandiri di lingkungannya. Mereka baru melakukan upaya P4GN pada lingkup yang kecil yaitu pada keluarga masing-masing. Sementara output dalam bentuk kerja sama dengan pihak swasta (PT. Pelindo II) sudah berjalan. Program Pemberdayaan Alternatif dapat memberi dampak yang positif pada indikator kemandirian dan peningkatan penghasilan. Sedangkan indikator alih profesi, penurunan kejahatan narkotika dan kriminalitas lainnya masih belum maksimal. Sementara itu, dalam hal ketahanan keluarga program Pemberdayaan Alternatif dapat menjadi salah satu cara untuk meningkatkan ketahanan keluarga melalui kemandirian ekonomi. Pemberian pelatihan dan juga peningkatan kesadaran masyarakat akan bahaya narkotika dapat menguatkan ketahanan keluarga pada masyarakat di kawasan rawan narkotika. Dengan demikian, program Pemberdayaan Alternatif yang dilaksanakan di RW.12 Kampung Muara Bahari telah sesuai dengan tujuan khusus dari program yaitu untuk meningkatkan peran dan kemandirian masyarakat di kawasan rawan narkotika. Sedangkan tujuan umum untuk menciptakan lingkungan yang bebas dan bersih dari penyalahgunaan dan peredaran gelap narkotika masih belum tercapai dengan optimal.

Program Pemberdayaan Alternatif tidak dapat berdiri sendiri dalam melakukan intervensi di kawasan rawan narkotika. Program Pemberdayaan Alternatif harus berjalan beriringan dengan pencegahan, pemberantasan, dan rehabilitasi. Indikator keberhasilan dari program Pemberdayaan Alternatif dapat dibuat lebih terukur agar mudah dilakukan evaluasi.

\section{UCAPAN TERIMA KASIH}

Penulis mengucapkan terima kasih kepada BNN Kota Jakarta Utara, tokoh masyarakat dan warga yang telah berpartisipasi dalam kegiatan ini.

\section{DAFTAR PUSTAKA}

Azizah, N. (2019). Pelatihan pemberdayaan istri nelayan melalui pelatihan digital marketing strategy (DMS) Darah Biru. Dinamisia : Jurnal Pengabdian Kepada Masyarakat, 3(1), 131-141. https://doi.og/10.31849/dinamisia.v3i1.2675

Dayamas, D. (2017). Cetak biru pemberdayaan masyarakat. Badan Narkotika Nasional.

Dayatif, D. (2017). Petunjuk teknis pemberdayaan alternatif masyarakat desa \& kota. Badan Narkotika Nasional.

Duwi, I., Sari, M., Septiani, P. E., Suri, U. A., \& Salamah, H. (2019). Pemberdayaan perempuan pesisir dalam mewujudkan kampung krumi untuk meningkatkan perekonomian desa bendar. Dinamisia: Jurnal Pengabdian Kepada Masyarakat, 3(1), 105-111. https://doi.org/10.31849/dinamisia.v3i1.2729

Fanaqi, Chotijah. \& Pratiwi, R. M. (2019). Partisipasi masyarakat dalam pencegahan narkoba di Garut. Jurnal Komunikasi Hasil Pemikiran dan Penelitian, 5(1), 160-176. https://doi.org/http://dx.doi.org/10.10358/jk.v5i1.589.g567

Fitriani, Y., Raharjo, T., \& Wibowo, H. (2011). Pengembangan Ekonomi Lokal Sebagai Alternatif. Prosiding KS, 163-168. 
ABDIMAS: Jurnal Pengabdian Masyarakat Universitas Merdeka Malang Volume 6, No. 4, November 2021: 600-612

Handayani, S. (2011). Pengaruh keluarga, masyarakat dan pendidikan terhadap pencegahan bahaya narkoba dikalangan remaja [Tesis, Universitas Indonesia]. Universitas Indonesia.

Hanita, M. (2020). Ketahanan nasional. Jakarta: UI Publishing.

Ikawati. (2016). Kontribusi ketahanan keluarga terhadap sikap remaja dalam penyalahgunaan narkoba. Jurnal PKS, 101-114.

Motif, I. A., Wisaksono, B., Endah, A. M., Astuti, S., Studi, P., Ilmu, S., Hukum, F., \& Diponegoro, U. (2016). Upaya penanggulangan tindak pidana penyalahgunaan narkotika oleh Badan Narkotika Nasional Kabupaten/Kota (BNNK) Karawang terhadap remaja di Kabupaten Karawang. Diponegoro Law Review, 5(3), 1-16.

Noor, M. (2011). Pemberdayaan masyarakat. Jurnal Ilmiah CIVIS, 1(2), 87-99. https://doi.org/10.26877/civis.v1i2/Juli.591

Nopitasari, Dian, \& Rostyaningsih, D. (2017). The implementation of these programs exist for handling social problems i.e. drug abuse conducted by the National Narcotics Agency through the efforts of prevention and eradication of Drug abuse and Dark Outlets (P4GN). Indonesian Journal of Public Policy and Management Review, 6, 832-845.

https://doi.org/10.14710/jppmr.v6i2.16219

P2M. (2019). Data Kawasan Rawan di Jakarta Utara 2019. Badan Narkotika Nasional Republik Indonesia.

Puslitdatin. (2020). Indonesia Drugs Report 2019. Badan Narkotika Nasional Republik Indonesia.

Saragih, R. (2017). Membangun usaha kreatif, inovatif dan bermanfaat melalui penerapan kewirausahaan sosial. Jurnal Kewirausahaan, 3(2), 26-34.

Subarkah, A. \& Pribowo (2017). Ketahanan keluarga dalam menghadapi bahaya penyalahgunaan narkotika, psikotropika, dan zat adiktif di Cirebon. Jurnal Ilmiah Pekerjaan Sosial, 16, 186-196. https://doi.org/10.31595/peksos.v16i1.105

Yulinda, A., \& Permata. (2013). Proses Pelaksanaan Program Pemberdayaan Alternatif Masyakarat Perkotaan Badan Narkotika Nasional Di RW 007 Komplek Permata, Jakarta Barat [Skripsi, Universitas Indonesia]. Universitas Indonesia.

Yunia, A., \& Pinariya, J. M. (2019). Rumah kreatif dan inovasi sebagai program pemberdayaan masyarakat Kampung Muara Bahari. Journal of Servite, 1(1), 25. https://doi.org/10.37535/102001120193 